\title{
PENERAPAN METODE TUTOR SEBAYA TERHADAP HASIL BELAJAR SISWA PADA KOMPETENSI DASAR MEMASANG SISTEM PENERANGAN DAN WIRING KELISTRIKAN DI SMK
}

\author{
Hanif A. Sidiq ${ }^{1}$, Dede Suhayat ${ }^{2}$, Tatang Permana ${ }^{3}$ \\ Universitas Pendidikan Indonesia \\ Jl. Dr. Setiabudhi No. 229 Bandung 40154 \\ hanif.ahmad@student.upi.edu
}

\begin{abstract}
ABSTRAK
Penelitian ini dilatarbelakangi oleh rendahnya aktivitas belajar dan hasil belajar siswa pada materi pembelajaran kelistrikan Kompetensi Dasar memasang sistem penerangan dan wiring kelistrikan. Tujuan dari penelitian ini untuk mengetahui aktivitas belajar dan hasil belajar siswa melalui penerapan metode Tutor Sebaya. Metode penelitian yang digunakan adalah metode Penelitian Tindakan Kelas (PTK) yang terdiri dari dua siklus yang dilakukan pada kelas XI TKR SMK Budi Raksa Lembang sebanyak 32 siswa. Metode tutor sebaya adalah metode belajar mengajar dengan bantuan seorang peserta didik yang kompeten untuk mengajar peserta didik lainnya. Pengumpulan data yang dilakukan untuk mengukur aktivitas belajar siswa yaitu dengan menggunakan lembar observasi dan pengumpulan data untuk mengukur hasil belajar siswa yaitu dengan menggunakan performance test. Hasil penelitian menunjukan bahwa adanya peningkatan aktivitas belajar siswa pada siklus I dan siklus II berturut-turut dalam kategori tinggi dan kategori sangat tinggi dan peningkatan hasil belajar siswa dengan $n$-gain dinormalisasi pada siklus I sebesar 0.61 dalam kategori sedang dan pada siklus II sebesar 0.77 pada kategori tinggi. Kesimpulannya bahwa dengan penerapan metode tutor sebaya dapat meningkatkan aktivitas belajar dan hasil belajar siswa pada materi pembelajaran kelistrikan Kompetensi Dasar memasang sistem penerangan dan wiring kelistrikan.
\end{abstract}

Kata kunci: tutor sebaya, aktivitas belajar, hasil belajar.

\section{PENDAHULUAN}

Sekolah Menengah Kejuruan (SMK) mulai menjadi prioritas bagi pemerintah sebagai salah satu lembaga pendidikan yang diharapkan dan dikembangkan sebagai lembaga pencetak lulusan yang siap kerja. SMK merupakan lembaga pendidikan yang memberikan bekal keterampilan kepada lulusannya untuk terjun langsung ke dunia kerja. Namun tidak mengesampingkan memberikan pengetahuan kepada lulusan untuk melanjutkan ke perguruan tinggi. Oleh karena itu, pembelajaran di SMK tidak hanya menekankan pada kognitif semata tetapi juga memperhatikan keterampilan afektif dan psikomotor (Kuswana, 2013).

Pengembangan keterampilan bukanlah hal baru dalam pendidikan, karena landasan untuk mengembangkannya sudah jelas. Sebagaimana yang tercantum dalam Undangundang Nomor 20 Tahun 2003 Tentang Sistem Pendidikan Nasional, Bab 1 Pasal 1 Ayat 1: Pendidikan adalah usaha sadar dan terencana untuk mewujudkan suasana belajar dan

\footnotetext{
${ }^{1}$ Mahasiswa Departemen Pendidikan Teknik Mesin FPTK UPI

2 Dosen Departemen Pendidikan Teknik Mesin FPTK UPI

${ }^{3}$ Dosen Departemen Pendidikan Teknik Mesin FPTK UPI
} 
proses pembelajaran agar peserta didik secara aktif mengembangkan potensi dirinya untuk memiliki kekuatan spiritual keagamaan, pengendalian diri, kepribadian, kecerdasan, akhlak mulia serta keterampilan yang diperlukan dirinya, masyarakat, bangsa dan negara. Undangundang Sistem Pendidikan Nasional tersebut mengamanatkan agar semua kegiatan pendidikan dalam upaya mengembangkan potensi kecerdasan dan keterampilan bisa berhasil. Termasuk untuk semua mata pelajaran yang ada di SMK, khususnya pada program keahlian Teknik Kendaraan Ringan terdapat mata pelajaran yang menuntut agar siswa memiliki keterampilan (Fathurrohman dan Sutikno, 2009).

Mata pelajaran kelistrikan di SMK merupakan salah satu mata pelajaran yang di uji kompetensikan. Salah satu kompetensi yang diuji kompetensikan adalah memasang sistem penerangan dan wiring (rangkaian) kelistrikan. Tentunya siswa dituntut untuk merangkai semua komponen sistem penerangan dan wiring kelistrikan dengan waktu yang ditentukan. Jika dalam waktu yang ditentukan siswa tidak berhasil menyalakan merangkai dengan benar, maka siswa dinyatakan tidak lulus dan harus melakukan perbaikan.

Hasil belajar siswa pada Kompetensi Keahlian Teknik Kendaraan Ringan (TKR) masih banyak yang di bawah Kriteria Ketuntasan Minimal (KKM) yang telah ditetapkan. Hasil belajar siswa dapat dilihat dari nilai hasil uji kompetensi yang dilaksanakan pada setiap akhir semester. Nilai yang diperoleh siswa pada kompetensi dasar memasang sistem penerangan dan wiring kelistrikan 65,6\% masih di bawah KKM.

Hal ini menuntut agar proses belajar mengajar harus berjalan lebih efektif, karena kegiatan belajar mengajar di sekolah merupakan kegiatan pokok. Berarti ketercapaian tujuan pendidikan dan pengajaran akan tergantung pada proses mengajar oleh guru dan aktivitas belajar yang dilakukan oleh siswa (Arifin, 2012). Terdapat beberapa faktor yang mengakibatkan siswa mengalami kesulitan belajar pada mata pelajaran kelistrikan diantaranya metode yang diterapkan oleh guru yang membuat aktivitas belajar siswa menjadi rendah.

Aktivitas belajar siswa pada saat KBM di kompetensi dasar memasang sistem penerangan dan wiring kelistrikan di SMK Budi Raksa Lembang masih terbilang belum maksimal. Hasil observasi diperoleh aktivitas belajar siswa, jumlah siswa yang tidak melakukan kegiatan awal sebanyak 14 siswa (43.75\%), tidak melakukan kegiatan inti sebanyak 11 siswa (34.37\%), tidak melakukan persiapan latihan sebanyak 18 siswa (56.25\%), dan tidak melakukan proses latihan sebanyak 22 siswa (68.75\%). Kondisi tersebut 
masih jauh dari harapan standar proses pembelajaran dan terlihat kegiatan belajar siswa masih rendah.

Salah satu faktor penyebab kesulitan belajar adalah aktivitas belajar siswa masih rendah. Bermacam karakter siswa didalam kelas membuat guru harus pintar dalam pemilihan metode pembelajaran (Sani, 2013). Kesalahan pemilihan metode pembelajaran akan menyebabkan materi pembelajaran kurang maksimal diterima oleh siswa. Setiap kelas ada siswa yang aktif dan ada juga siswa pasif (Fathoni dan Riyana, 2009). Siswa pasif cenderung malu dan sungkan untuk bertanya kepada guru apabila tidak mengerti dan mereka lebih leluasa bertanya kepada sesama siswa. Sehingga metode pembelajaran yang tepat salah satu upaya untuk mengatasi permasalahan yang ada yaitu dengan menggunakan metode tutor sebaya.

Tutor sebaya dikenal dengan pembelajaran teman sebaya atau pemberian pembelajaran antar siswa atau peserta didik (Safrudin, 2014). Peserta didik yang lebih mampu menyelesaikan pekerjaannya sendiri, dan kemudian membantu peserta didik lain, yang kurang mampu (Arjanggi, 2010). Hal ini merupakan strategi untuk mendukung pengajaran, sesama peserta didik didalam kelas.

Melalui penerapan metode ini dalam pembalajaran kelistrikan pada kompetensi dasar memasang sistem penerangan dan wiring kelistrikan. Diharapkan aktivitas belajar kelistrikan siswa akan lebih tinggi dan pemahaman mereka akan meningkat serta meningkatkan hasil belajar siswa. Selain itu metode ini juga dapat menumbuhkan tanggung jawab siswa terhadap pembelajarannya sendiri dan membuat siswa menjadi lebih aktif (Maryani, 2010).

\section{METODE PENELITIAN}

Peneitian ini menggunakan metode penelitian tindakan kelas. Metode ini mengkaji suatu pendekatan pembelajaran dengan tujuan untuk memperbaiki proses belajar mengajar dan meningkatkan hasil belajar dikelas melalui perubahan dan perbaikan. Secara garis besar terdapat empat kegiatan utama yang ada pada setiap siklus, yaitu: perencanaan, tindakan, pengamatan, dan refleksi. Tujuan PTK adalah untuk memperbaiki dan meningkatkan layanan profesional guru dalam menangani permasalahan di kelas. Tujuan tersebut dapat dicapai dengan melakukan refleksi untuk mendiagnosis keadaan dan mencoba secara sistematis tindakan alternatif dalam pemecahan masalah di kelas. Populasi dalam penelitian ini adalah siswa Teknik Kendaraan Ringan kelas XI SMK Budi Raksa Lembang, Sampel 
diambil dengan menggunakan teknik sampling jenuh. Sampel dalam penelitian ini populasinya dijadikan sampel sebanyak 32 orang. Instrumen yang digunakan adalah lembar observasi aktivitas guru mengajar, lembar observasi aktivitas belajar siswa, pretest, dan posttest untuk mengukur hasil belajar. Pengujian validitas isi dengaan cara judgment.

\section{HASIL PENELITIAN}

Data hasil observasi aktivitas belajar siswa siklus I dalam kategori tinggi. Hasil belajar siswa pada siklus I saat pre-test tergolong rendah. Perolehan skor pre-test terendah diperoleh nilai 16,5 , sedangkan skor tertinggi pada siklus I diperoleh nilai 68,6 . Rata-rata skor pre-test siswa sebesar 37,9. Jumlah siswa yang memenuhi nilai KKM (Ketuntasan Kriteria Minimal) belum ada, (KKM SMK Budi Raksa Lembang $\geq 75,0$ ).

Hasil belajar siswa pada siklus I saat post-test masih belum maksimal. Perolehan skor post-test terendah diperoleh nilai 41,3, sedangkan skor tertinggi diperoleh nilai 100. Ratarata skor nilai post-test siswa sebesar 75,5. Hasil post-test, siswa yang memenuhi nilai KKM hanya ada 14 siswa (43,7\%), sedangkan minimal jumlah siswa yang harus memenuhi KKM lebih dari atau sama dengan $(\geq)$ 75,0\% dari seluruh jumlah siswa. Apabila $75 \%$ dari jumlah siswa yang mengikuti proses belajar mengajar atau mencapai taraf keberhasilan minimal, optimal, atau bahkan maksimal, maka proses belajar mengajar berikutnya dapat menbahas pokok bahasan baru (Djamarah dan Zain, 2006). Rata-rata nilai N-Gain, yakni rata-rata peningkatan hasil belajar seluruh siswa pada siklus I sebesar 0,61, yang termasuk masih dalam kategori sedang. Hasil penelitian pada pembelajaran siklus I menunjukkan pembelajaran pada kompetensi dasar memasang sistem penerangan dan wiring kelistrikan dengan menggunakan metode tutor sebaya masih kurang maksimal, masih terdapat kekurangan dan perlu adanya perbaikan pada siklus II. Berdasarkan refleksi dengan guru mata pelajaran dan data-data yang terkumpul pada pembelajaran siklus I, kekurangankekurangannya antara lain: hasil belajar siswa yang memenuhi KKM masih $<75,0 \%$ dari jumlah seluruh siswa, sehingga harus dilanjutkan dengan siklus II, masih ada siswa yang terlambat masuk sekolah, masih ada siswa yang tidak memakai baju praktik, dan masih kurangnya siswa memanfaatkan waktu dalam praktik merangkai sistem penerangan.

Hasil refleksi tersebut kemudian dibuat perencanaan perbaikan pada siklus II sebagai berikut: urutan latihan praktik siswa diatur sesuai no absen, sehingga lebih teratur dan mudah untuk mencatat saat mengisi lembar observasi aktivitas belajar siswa. Setiap siswa diminta tidak datang terlambat. Setiap siswa diminta untuk memakai baju praktik. Waktu 
pembelajaran diperhatikan sesuai alokasi waktu yang diberikan. Penelitian pada siklus II, karena hasil belajar siswa masih kurang, terlihat dari jumlah siswa yang memenuhi KKM masih kurang dari 75\% dari jumlah total siswa yaitu hanya 14 siswa $(43,7 \%)$.

Data hasil observasi aktivitas belajar siswa siklus I dalam kategori tinggi. Hasil belajar siswa pada siklus II saat pre-test tergolong rendah. Perolehan skor pre-test terendah diperoleh 29,4, sedangkan skor tertinggi diperoleh 78,8. Rata-rata skor pre-test siswa sebesar 53,3. Jumlah siswa yang memenuhi nilai KKM sudah ada 3 orang, (KKM $\geq 75,0)$. Hasil belajar siswa pada siklus II saat post-test sudah menunjukan kearah peningkatan. Perolehan skor post-test terendah diperoleh 51.76 (skala 100), sedangkan skor tertinggi diperoleh 100. Rata-rata skor nilai post-test siswa sebesar 89,2. Hasil post-test, siswa yang memenuhi nilai KKM mencapai 31 siswa $(96,8 \%)$, sehingga sudah terpenuhi ketentuan minimal jumlah siswa yang mencapai $\mathrm{KKM} \geq 75,0 \%$ dari seluruh jumlah siswa (Guru mata pelajaran kelistrikan). Sementara itu, rata-rata nilai $N$-Gain, yakni rata-rata peningkatan hasil belajar seluruh siswa pada siklus II sebesar 0,77 , termasuk dalam kategori tinggi.

\section{PEMBAHASAN}

Aktivitas guru mengajar perlu dilihat, diukur, dan dinilai. Hal tersebut harus dilakukan karena bagaimanapun keberhasilan aktivitas belajar dan hasil belajar siswa sangat dipengaruhi oleh keterampilan guru mengajar. Keterampilan mengajar dalam hal ini adalah tindakan seorang guru dalam menerapkan metode pembelajaran tutor sebaya. Proses belajar siswa akan berpengaruh juga terhadap hasil belajar siswa. Belajar adalah sebagai pengalaman sendiri dalam interaksi dengan lingkungannya (Slameto, 2003). Interaksi dengan lingkungan inilah, peran guru untuk menciptakan siswa berinteraksi dengan lingkungannya dalam bentuk penerapan metode pembelajaran yang dipakai. Oleh karena itu, metode yang dipakai hendaknya mengandung banyak aktivitas belajar. Hal tersebut bertujuan agar setiap siswa melakukan proses belajar.

Hasil observasi aktivitas guru dari siklus I ke siklus II, aktivitas guru mengajar dalam menerapkan metode tutor sebaya mengalami peningkatan. Rata-rata aktivitas guru mengajar di siklus I adalah 93,3\% sedangkan rata-rata aktivitas guru mengajar di siklus II adalah $100 \%$. Penerapan metode pembelajaran tutor sebaya yang dilakukan oleh guru semakin membaik. Sementara itu, aktivitas siswa pada siklus II dengan metode tutor sebaya semakin membaik yaitu $84 \%$ Hal ini memperlihatkan bahwa kegiatan refleksi dari siklus I berperan penting untuk perbaikan aktivitas siswa pada siklus ke-2. Semakin baiknya aktivitas guru 
mengajar dengan metode tutor sebaya, akan berpengaruh juga terhadap semakin baiknya aktivitas belajar siswa. Penerapan metode pembelajaran tutor sebaya semakin membaik, sehingga dapat disimpulkan bahwa guru dipastikan menerapkan metode tersebut dengan tujuan untuk meningkatkan aktivitas belajar dan hasil belajar siswa (Prasetya, 2016).

Kaitan antara guru mengajar, aktivitas belajar siswa, dan hasil belajar siswa. Aktivitas belajar siswa adalah keterlibatan siswa dalam bentuk sikap, pikiran, perhatian dalam kegiatan belajar guna menunjang keberhasilan proses belajar mengajar dan memperoleh manfaat dari kegiatan tersebut (Kunandar, 2008). Pendapat tersebut mengatakan bahwa keterlibatan siswa dalam aktivitas belajar akan menunjang keberhasilan proses belajar. Aktivitas belajar siswa pada penelitian ini dilihat berdasarkan hasil observasi. Kegiatan observasi dilakukan oleh seorang observer dengan mengisi lembar observasi untuk melihat aktivitas belajar setiap siswa.

Data yang didapat siklus I, aktivitas belajar siswa adalah 77\% Aktivitas belajar tersebut termasuk dalam kategori tinggi. Hasil aktivitas belajar siswa yang terkategori masih tinggi tersebut juga bisa dipengaruhi oleh keberhasilan aktivitas guru dengan penerapan metode tutor sebaya (Wahyuni, 2017). Aktivitas guru pada siklus I tersebut hanya sebesar 93,3\%. Sementara itu, pada siklus II, aktivitas belajar siswa adalah 84\%. Rata-rata aktivitas belajar tersebut termasuk dalam kategori sangat tinggi. Aktivitas belajar siklus II tersebut juga dipengaruhi oleh aktivitas yang dilakukan oleh guru pada siklus II. Aktivitas guru pada siklus II tersebut sebesar 100\%. Oleh karena itu, semakin baik penerapan metode tutor sebaya, semakin baik pula aktivitas belajar siswa. Data tersebut terbukti secara empiris bahwa penerapan metode pembelajaran tutor sebaya dapat meningkatkan aktivitas belajar siswa (Apnormi, 2013). Demi menunjang siswanya untuk lebih banyak melakukan aktivitas belajar. Semakin baik aktivitas belajar siswa, akan berpengaruh juga terhadap hasil belajarnya. Oleh karena itu, seorang guru disarankan untuk menggunakan metode pembelajaran yang menunjang lebih banyak aktivitas belajar siswa (Sardiman, 2010).

Hasil belajar siswa pada penelitian ini diukur dengan menggunakan post-test. Sebelum siswa melaksanakan post-test, mereka melaksankan pre-test terlebih dahulu, guna untuk mengetahui kemampuan awal siswa (aspek psikomotor) dan juga mengetahui peningkatan hasil belajarnya. Berdasarkan data empiris, dihasilkan peningkatan hasil belajar pada siklus I ( $N$-Gain) sebesar 0,61 (kategori sedang), sedangkan peningkatan hasil belajar pada siklus II (N-Gain) sebesar 0,77 (kategori tinggi). Berdasarkan data hasil belajar siswa siklus I ke 
siklus II, terbukti secara empiris bahwa penerapan metode pembelajaran tutor sebaya dapat meningkatkan hasil belajar siswa.

Penerapan metode tutor sebaya ini sudah menunjukkan peningkatan hasil belajar yang baik. Hasil penelitian ini diharapkan agar menjadi landasan bagi guru-guru untuk memilih metode pembelajaran yang dapat meningkatkan aktivitas belajar siswa (Sudiasih, 2011). Aktivitas belajar siswa selama mengikuti pembelajaran merupakan faktor yang berpengaruh terhadap hasil belajarnya. Tanpa disadari siswa saat melakukan aktivitas belajar akan berpengaruh terhadap pemahaman materi pelajaran, sehingga hasil belajarnya lebih meningkat.

\section{KESIMPULAN}

Kesimpulan penelitian ini sebagai berikut: terjadi peningkatan aktivitas belajar siswa dipembelajaran siklus I yang termasuk pada kategori tinggi dan dipembelajaran siklus II pada kategori sangat tinggi melalui metode pembelajaran tutor sebaya pada kompetensi dasar merangkai sistem penerangan dan wiring kelistrikan. Terjadi peningkatan hasil belajar siswa dipembelajaran dengan nilai n-gain dinormalisasi siklus I termasuk pada kategori sedang dan siklus II pada kategori tinggi melalui penerapan metode pembelajaran tutor sebaya pada kompetensi dasar merangkai sistem penerangan dan wiring kelistrikan

\section{REFERENSI}

Apnormi (2013). Penerapan Pembelajaran Kooperaif Tutor Sebaya untuk Meningkatkan Hasil Belajar Siswa pada Materi Lingkaran di Kelas VIII-G SMP Negeri 9 Malang. Jurnal Pendidikan Matematika. 1(3). hlm. 47.

Arifin, Z. (2012). Evaluasi Pembelajaran. Bandung: Remaja Rosdakarya.

Arjanggi, R. (2010). Metode Pembelajaran Tutor Teman Sebaya Meningkatkan Hasil Belajar Berdasar Regulasi-Diri. Sosial Humaniora.14( 2). hlm. 94.

Djamarah, S.B. dan Zain A. (2006). Strategi Belajar Mengajar. Jakarta: PT. Rineka Cipta.

Fathoni, T. \& Riyana, C. (2009). Kurikulum \& Pembelajaran/TIM pengembang MKDP Kurikulusm da Pembelajaran Ed.3 Cet 4. Bandung: Jurusan Kurtekpen FIP UPI.

Fathurrohman, P. \& Sutikno, S. (2009). Strategi Belajar Mengajar Melalui Penanaman Konsep Umum \& Konsep Islami. Bandung: TP. Refika Aditama.

Kunandar. (2008). Langkah mudah penelitian Tindakan Kelas sebagai Pengembangan Profesi Guru. Jakarta: PT.Raja Grafindo Persada.

Kuswana, W. S. (2013). Filsafat Pendidikan Teknologi Vokasi dan Kejuruan. Bandung: Alfabeta. 
Maryani. (2010). Penerapan Metode Pembelajaran Tutor Sebaya untuk Meningkatkan Prestasi Belajar Akuntansi pada Siswa Kelas X AK 1 SMK Batik 2 Surakarta. Jurnal Pendidikan Ilmu pengetahuan Sosial. 1(2).hlm 31.

Prasetya, D.J. (2016). Penerapan Metode Pembelajaran Peer Teaching Untuk Meningkatkan Hasil Belajar Siswa Kelas X Pada Mata Pelajaran Dasar dan Pengukuran Listrik di SMK N Nusawungu. Jurnal Pendidikan Teknik Mekatronika. 6 (4). hlm. 314.

Safrudin. (2014). Penggunaan Tutor Sebaya untuk Meningkatkan Hasil Belajar Fisika Kelas X B Di SMA Negeri 1 Gumbasa. Jurnal Pendidikan Fisika Tadulako. 1 (3). hlm. 46.

Sani, R. A. (2013). Inovasi Pembelajaran. PT. Bumi Aksara: Jakarta.

Sardiman, A.M. (2010). Interaksi dan Motivasi Belajar Mengajar. Jakarta: PT. Raja Grafindo Persada.

Slameto. (2003). Belajar dan Faktor-faktor yang Mempengaruhinya. Jakarta: Rineka Cipta.

Sudiasih. (2011). Penerapan Metode Pembelajaran Tutor Sebaya Untuk Meningkatkan Hasil Belajar Menggambar Busana di SMK Ma'arif 2 Sleman. Jurnal Pendidikan Teknik Busana. 3(1). hlm. 15.

Wahyuni, S. (2017). Meningkatkan Hasil Belajar Materi Kewirausahaan Melalui Tutor Sebaya. Jurnal Penelitian Tindakan dan Pendidikan. 3 (1). hlm. 95. 